\title{
Comparing languages and cultures: Parametrization of analytic criteria
}

\author{
Barbara LEWANDOWSKA-TOMASZCZYK
}

\author{
State University of Applied Sciences in Konin \\ Konin, Poland
}

\begin{abstract}
The focus of the paper is to present arguments in favour of a complex set of areas of reference in cross-linguistic analyses of meanings, aimed in particular at the identification of a set of relevant analytic criteria to perform such a comparison. The arguments are based on lexicographic and corpus linguistic data and specifically on the polysemic concept of integrity in English and its lexical counterparts in Polish. It is generally assumed in Cognitive Linguistics, which is taken as the basic framework of the present study, that meanings, which are defined as convention-based conceptualizations, are not discrete entities, fully determined, even in fuller context but rather they are dynamic conventional conceptualizations ${ }^{1}$. Therefore, it is considered essential to identify first their basic, prototypical senses and then their broad meanings, which include, apart from the core part, their contextual, culture-specific, and connotational properties, defined in terms of a parametrized set of semasiological as well as onomasiological properties. The study methodology has also been adjusted towards this multifocused analysis of linguistic forms and considers the interdisciplinary - linguistic, psychological, cultural and social domains to identify the cultural conceptualizations of the analysed forms. In the present case a cognitive corpus-based analysis in monolinguistic English contexts and in the English-to-Polish and Polish-to-English translation data of lexicographic and parallel corpus materials, as well as cultural dimensions will be exemplified to conclude with a parametrized system of cognitive cross-linguistic tertia comparationis to more fully determine their broad linguistic meanings.
\end{abstract}

Keywords: analytic criteria, Cognitive Linguistics, cultural conceptualizations, parametrization, tertium comparationis

\section{For citation:}

Lewandowska-Tomaszczyk, Barbara. 2021. Comparing languages and cultures: Parametrization of analytic criteria. Russian Journal of Linguistics 25 (2). 343-368. DOI: https://doi.org/10.22363/2687-0088-2021-25-2-343-368

${ }^{1}$ This is particularly evident in the case of abstracted lexical meanings in which schematization plays a role, especially when contrasted with what Langacker calls "usage events, i.e. the actual pronunciations and contextual understandings" (Langacker 2008: 16), more determined, although also subject to interpretation. 


\title{
Сравнение языков и культур: параметризация аналитических критериев
}

\author{
Барбара ЛЕВАНДОВСКА-ТОМАШЧИК \\ Государственная высшая профессиональная школа в Конине \\ Конин, Польша
}

\begin{abstract}
Аннотация
Цель статьи - представить аргументы в пользу комплексного набора параметров кросслингвистического анализа значений, направленного на идентификацию релевантных аналитических критериев для осуществления такого сравнения. Аргументы опираются на данные словарей и корпусной лингвистики, а именно на полисемантичное понятие integrity (целостность) в английском языке и соответствующие ему понятия в польском. В когнитивной лингвистике, которая выступает как теоретическая основа данного исследования, традиционно считается, что значения, определяемые как концептуализации, основанные на конвенциях, не являются отдельными полностью устоявшимися сущностями даже в развернутых контекстах, а скорее представляют собой динамические конвенциональные концептуализации. Таким образом, важно идентифицировать их основные, прототипические cмыслы, которые, помимо ядерной части, включают контекстуальные, культурно-специфические свойства и коннотации, определяемые в терминах параметрического набора как семасиологических, так и ономасиологических свойств. Методология исследования также адаптирована к многонаправленному анализу языковых форм и учитывает междисциплинарные лингвистические, физиологические, культурные и социальные - факторы для идентификации культурных конщептуализаций анализируемых форм. В данном случае будет представлен когнитивный корпусный анализ данных из словарей, из английских текстов, параллельных корпусов (английского и польского), а также их культурные параметры с целью вывести параметрическую систему когнитивных кросс-лингвистических основ сравнения - tertia comparationis - для более полного определения языковых значений.
\end{abstract}

Ключевые слова: аналитические критерии, когнитивная лингвистика, культурная конщептуализация, параметризация, tertium comparationis

\section{Для цитирования:}

Lewandowska-Tomaszczyk B. Comparing languages and cultures: Parametrization of analytic criteria. Russian Journal of Linguistics. 2021. Vol. 25. № 2. P. 343-368. DOI: https://doi.org/10.22363/2687-0088-2021-25-2-343-368

\section{Focus of the paper}

The focus of the paper is to present arguments in favour of a complex set of areas of reference in cross-linguistic analyses of meanings, aimed in particular at the identification of a set of relevant analytic criteria to perform such a comparison. The arguments are based on lexicographic and corpus linguistic data and specifically the polysemic concept of integrity in English and its lexical counterparts in Polish. It is generally assumed in Cognitive Linguistics, which is taken as the basic framework of the present study, that meanings, which are defined as convention-based conceptualizations, are not discrete entities, fully determined, 
even in fuller context ${ }^{2}$. Therefore, I would like to argue that it is essential to identify first the basic, prototypical senses of concepts and then their broad meanings, which include, apart from the core part, their contextual, culture-specific, and connotational properties defined in terms of a parametrized set of their systemrelated semasiological as well as onomasiological properties, emphasizing the significant role of extralinguistic reality in the process of naming. Thus it is also needed to adjust the study methodology towards a multifocused analysis of linguistic forms and consider the interdisciplinary - linguistic, psychological, cultural and social domains to identify the cultural conceptualizations of the analysed forms. In the present case a cognitive corpus-based analysis in monolinguistic English contexts and in the translation data of lexicographic and parallel corpus materials will be presented, and relevant cultural dimensions will be exemplified to conclude with a parametrized system of cognitive cross-linguistic tertia comparationis to more fully determine their lingistic meanings.

The paper elaborates on and presents arguments for a complex set of areas of reference in cognitive cross-linguistic analyses of what is considered broad linguistic meanings (Lewandowska-Tomaszczyk 1989, 2012, 2012a). Examples of contrastive cognitive-structural parameters of discourse and a corpus-based cognitive analysis of selected forms in English and Polish meanings are presented, in particular a comparison of the English form integrity and its cluster equivalents in Polish (Lewandowska-Tomaszczyk 2017). It is claimed that to uncover areas of analogy and difference cross-linguistically it is considered necessary to identify and analyse both a parametrized set of their semasiological as well as onomasiological properties (Geeraerts 2015), i.e., both the inherent meaning as well as the naming processes of a particular part as perceived in the outside world. To contextualize the study, the data obtained from relevant corpus materials will be discussed in the cultural context, originally inspired by culture studies (e.g., Hofstede 1980, Nora 1992, Trompenaars and Hampden-Turner 1997) and developed in linguistics and translation studies (e.g., Snell-Hornby 2006, Sdobnikov 2019, Sharifian 2017, Tirado 2019). In the conclusion, a parametrized system of comparison criteria is presented for the cross-linguistic contrastive analysis.

\section{Comparison criteria}

One of the first Cognitive Linguistic attempts to capture similarities and contrasts in different semantic systems is to be found in the seminal publication Women, Fire and Dangerous Things by George Lakoff (1987), who proposes four types of what he calls Commensurability Criteria to analyze language contrasts according to particular frames of reference.

The first of these criteria is a truth-conditional comparison, which can be summed up as the original - formal - translatability criterion. The conditions under

${ }^{2}$ This is particularly true of context-free abstracted, less specific, lexical meanings in which schematization plays a role, when contrasted with what Langacker calls "usage events, i.e. the actual pronunciations and contextual understandings" (Langacker 2008: 16). 
which a sentence in L1 and a sentence in L2 are true or false, that is information whether they are identical or different in this respect, is a criterial factor in this case.

The criterion of use refers to a distributional range of particular language elements, i.e., the extent to which the range of use of such lexical elements in English as e.g., to sit in Mary is sitting in this armchair but also The cup is sitting on the shelf, corresponds to different verb uses in other languages. In the example [The products] may sit together on the shelf, and the consumer may think that those marked with $C E$ are better than the others ${ }^{3}$ the forms sit in these examples will correspond to stand or lie in other languages (e.g., Pol. produkty stoja 'stand' or leża 'lie' na półce 'on the shelf'; siedza 'sit' might be used in marked contexts).

The framing criterion combines the linguistic knowledge with the knowledge of the outside world. Different object or event frames or schemata, which regulate a top-down perspective on individual meanings are used in different languages e.g., in English the preference on the menu list is to treat some vegetables as individual entities used in the plural form e.g., the use of carrots and peas in the plural form in the English phrase casserole with ground beef, carrots, and peas, while users of other languages (e.g., Polish) perceive them as a mass and use the sigular (generic) noun in such cases (Pol. $z$ marchewka i groszkiem lit. 'with carrot and pea').

Finally, the organizational criterion reflects distinct cross-linguistic perspectives on objects within a given category as in the cases of polysemy, which will be more thoroughly explored in the further sections of this paper. Such cases represent distinct conceptual organization within semantic-conceptual categories across languages (Lewandowska-Tomaszczyk 2007). This criterion is evident in the case of conceptual or lexical gaps in some languages as in English, for example, a fully lexicalized concept of hubris - negative pride is absent, while it is present in other languegs (e.g., Pol. pycha 'hubris' versus duma 'pride'). Such and other cases of commensurability deficits or asymmetries cause meaning reconceptualization (Lewandowska-Tomaszczyk 2010) across languages and are evident in the analysis of translated texts.

The re-conceptualization processes, connected with inherent meaning approximation in communication (cf. Lewandowska-Tomaszczyk, 2010) involve both changes in the content of linguistic units from one language to another but are also embedded in the constructional properties of language, i.e., its syntax and morphology (Goldberg 1994). They can also reside in the perception components and influence possible construals of a scene. Crucial to the notion of cross-linguistic comparison is also the concept of profiling, in which a profile of an expression is, to quote Langacker (1991: 551), "the entity that the expression designates, a substructure within its base that is obligatorily accessed, accorded special prominence, and functions as the focal point within the immediate scope of predication". Thus, profiling is an aspect of construal, in terms of which semantic differences can be accounted for in the same language or in the comparison with other linguistic systems. The close links between sound and meaning as a subject

${ }^{3}$ eur-lex.europa.eu 
of cross-linguistic and cultural variation, reflected in distinct sound symbolic clusters and particular sounds, are also clearly noted in such cases, just as are the similarities and contrasts between the perception of figures and event construal, e.g., in the well-known poem Jabberwocky by Lewis Caroll ${ }^{4}$ as rendered into other languages:

(1) Original English text:

'Twas brillig, and the slithy toves

Did gyre and gimble in the wabe;

All mimsy were the borogoves,

And the mome raths outgrabe.

(2) German: Der Jammerwoch Robert Scott

Es brillig war. Die schlichte Toven

Wirrten und wimmelten in Waben;

Und aller-mümsige Burggoven

Die mohmen Räth' ausgraben.

(3) Italian: Il Giabervocco 5

S'era a cocce e i ligli tarri

girtrellavan nel pischetto,

tutti losci i cencinarri

suffuggiavan longe stetto

(4) Russian: Бармаглот

Варкалось. Хливкие шорьки

Пырялись по наве,

И хрюкотали зелюки,

Как мюмзики в мове.

(5) Polish: Dżabbersmok (Maciej Słomczyński)

Było smaszno, a jaszmije smukwijne

Świdrokrętnie na zegwniku wężały,

Peliczaple stały smutcholijne

I zbłąkinie rykoświstąkały

The phonetic symbolism - distinct in each of the above versions, rhythm and rhyme in their fully language-specific forms with longer, more vocalic vocing in the Slavic languages and in Italian opposing the consonantal codas in the English original and its cognate German, contribute to a different portrayal of the scene and event contrual. The resulting figurative usages, i.e., mapping operations of one domain onto another in metaphor or a part of a domain onto the whole domain in metonymy, or else in their combinations (metaphtonymy), and in other tropes, present yet other types of cross-linguistic contrasts in linguistic meaning and cultural conceptualizations (Sharifian 2017). To exemplify this phenomenon, we observe that while for example in the Arabic proverb in (5) (Ba-awaidhan

${ }^{4}$ The translations accessible at https://lyricstranslate.com

${ }^{5} \mathrm{https}$ ://yricstranslate.com/en/jabberwocky-il-giabbervocco.html 
2020: 52), family and relatives are mapped onto the scorpion frames, in English, as in the example (6) below, they are perceived metonymically, although their overall interpretations in both languages do not vary extensively:

(6) Paverb: عقارب الاقارب

Transliteration: al-agareb aga'reb.

Gloss: [the-relatives] [scorpions].

Translational equivalent: The relatives are scorpions.

The proverb above is counterbalanced by a contrary thought in Arabic: None but a mule denies his family ${ }^{6}$.

The tenor of English family and relatives sayings may be similar in both cultures in that family and relatives are perceived either positively or negatively but the metaphor source domains are clearly culurally entrenched (Sharifian 2017) ${ }^{7}$ and use distinct Source Domains in figurative language as e.g., in the English Some of the most poisonous people come disguised as family ${ }^{8}$.

The picture of family appears double-faceted in both cultures. Athough in both family is appreciated and decribed as supportive and helping on the one hand, it is also perceived in a more negative light and portrayed in terms of negative culturespecific points of reference (scorpion versus poison) on the other. And yet, in this case too, there are obvious cross-cultural similarities here: effects of closer encounters with either a scorpion or a poison might turn out to be similar. Thus, although different culture-specific points of reference and Source Domains are used across these languages, the process of metaphorization will invariably be a human universal cognitive ability which can serve as legitimate framing when search for meaning similarities and contrasts is taking place.

The conclusion from the examples discussed above is that meaning systems are calibrated to an extent across languages, which represents a typical crosslanguage state of affairs. Furthermore, any equivalents in such cases can only be considered solely of an approximative type, and should be analysed as a part of complex Event scenarios ${ }^{9}$. A speech event includes the so-called illocutionary components of speech events (Lewandowska-Tomaszczyk 1989: 78), involving an extended cultural-social conditioning of speech acts when compared with the original account by John L. Austin 1955), their cognitive modelling, their linguistic

${ }^{6}$ Source: https://proverbicals.com/family

${ }^{7}$ The contribution of the place and function of culture in shaping linguistic meanings has been identified in numerous approaches to meaning such as e.g., Palmer (1996), Goddard and Wierzbicka (2014), Wierzbicka (1992, 1997), Larina et al. (2020), Gladkova and Larina (2018a,b), and many others.

${ }^{8} \mathrm{https}: / /$ www.lookupquotes.com/quote_picture_detail.php?quote_url=some-of-the-mostpoisonous-people-come-disguised-as-family\&quote_id $=41032$

${ }^{9}$ Apart from earlier philosophical (e.g., Ingarden 1935, Wittgenstein 1953) and formal semantic approaches (Vendler 1957, von Wright 1963) to the concept and definition of event and event scenarios, the most widely recognized contribution in Cognitive Linguistics was proposed by Charles Fillmore (1985) in his Frame Semantics model. 
realization as well as discourse consequences in terms of responses and reactions. Event illocutionary components cover broad socio-cultural and demographic context conditions. The list below represents a schema of the constituents of Speech Events:

\section{Constituents of Speech Event comparison in Contrastive Linguistic analysis:}

- Networks of illocutionary components of given L1 and L2 units in terms of their prototypical and peripheral configurations

- Discourse consequences of given sequences in terms of prefernce organization (expected options and actual realizations) in L1 and L2

- Linguistic forms in L1 and L2 realizing given units and their responses in terms of their potential syntactico-semantic patterns

The exchange below represents an example of a complex event of complimenting analysed in Lewandowska-Tomaszczyk (1989): Person A complements person B on her looks and B responds. The full description of every such event includes a network of illocutrionary components which involve a set of cognitive cultural, and social conditioning, its verbal and non-verbal discourse consequences (real or staged embarrassment in this case) as well as their actual linguistic realization. When contrasted to a similar event in another language and culture - such sets of constituents identify cross-cultural and cross-linguistic similarites and differences. The exchange in (7) took place at an English university before classes:

(7) A: You look as fetching as ever today

B: Oh shucks, what can I say?

The lexical unit fetching in this context is synonymus to ${ }^{10}$ attractive, appealing, adorable, sweet, winsome, pretty, etc. The speech event of compliment in this case includes both cultural-social conditioning of speech acts (A (male student, 19) compliments B (female student, 19), the internal and external context conditions (A and B regularly meet at classes, A wants to invite B to dinner), the wording A used, and B's answers/reactions). In other words to account for a compliment content of a particular speech event, the cognitive, cultural, and linguistic aspects of the exemplified exchange, their linguistic realization as well as discourse consequences in terms of responses and reactions, have to be taken into consideration. Moreover, the proper interpretation of the concepts that can be seen as metaphorical (fetching versus to fetch) or the exclamation shucks, which might express shyness or embarasement, itself a euphemism of the stronger shit, must be considered. A parallel analysis in another language needs to be completed by the identification of similarities and contrasts in each of the properties of the systems., e.g., Polish even less direct responses to compliments, e.g., negation of the compliment (e.g., B1 response: Pol. Przesadzasz chyba! Ledwo żyję 'You must be exaggerating! I'm half-dead'). Both English and Polish answers open up further

${ }^{10} \mathrm{https}: / /$ www.google.com/search?client=firefox-b-d\&q=fetching+definition 
discourse options of exhanges as e.g., when A's compliement is considered a preparatory pre-act to the invitation in this context, to counterbalance B's possible face-threatening response to A, namely, her refusal, rejection of the invitation ${ }^{11}$.

\section{On the qualitative and quantitative planes}

Apart from the qualitative comparison, language quantitative criteria are of significance in a contrastive study (Lewandowska-Tomaszczyk 2012a). Language corpora and relevant corpus tools provide ways to generate frequencies automatically. The parameters available for scrutiny involve:

Quantitative parameters

- Frequencies: (i) in general language, (ii) in context-specific variety

- quantitative distributional facts

- sentence length

- type/token

- lexical density (low frequency - high frequency)

There are other criteria which might require a combination of numerical frequency values with a qualitative lexical and discourse analysis. One of such criteria is the phenomenon of naturalness, which embraces frequency and the contextual preference system. The frequency characteristics will more fully contribute to a qualitative factor with respect to the examined data, namely, the degree of naturalness associated with individual constructions. For example, contrasting some English gerundive structures (19 cases) such as ${ }^{12}$.

(8) Maybe this was due to my always having eaten a diet rich in red meat against 7,027 cases of eat:

(9) I always eat hamburger and chips on Thursdays

and 115 of have eaten

(10) We have eaten enough (115)

shows some preference towards the finite syntax in these cases when contrasted with the gerundive one, as noted in their usage-based parameter.

The research task involving a cross-linguistic comparison is thus built around identifying a contrastive similarity as a dynamic notion across languages, represented as a cline exhibiting a gradual increase in diversification. The degree of equivalence between L1 and L2 structures can thus be measured in terms of the reference categories mentioned above such as the typology of the category of naturalness, as well as categorization levels, prototypicality, image-schemata and their extensions, profiling and construal relations of various types.

${ }^{11}$ See Lewandowska-Tomaszczyk (1989) for this and other examples and details of the complex praising and complimenting speech events interpretation.

${ }^{12}$ The structures with eat in all of the forms used in examples (8-10) are identified in the BNC at http://pelcra.clarin-pl.eu/ 
It is needless to say that in the context of such inter-language divergences there is a clear asymmetry between languages in terms of what I call a displacement of senses, such as prototypical and extended meaning shifts or e.g., referential, conceptual or lexical gaps in one language against another.

While examining an individual lexical item from the perspective of a system, one can identify its meaning in terms of multidimensional networks of meanings, which reflect its distributional characteristics and position in the system, e.g., synonymy and oppositeness, inter-categorial similarities and oppositeness as well as polysemic links. From the usage perspective, some of these dimensions are more salient than others. The reason is that discourse is an active factor in meaning construction. It can reinforce some and weaken other dimensions. Degrees of contrastive correspondences in the languages also represent what is referred to as approximations, leading to inter- and intra-lingual mismatches in some of the cases (cf. Dziwirek \& Lewandowska-Tomaszczyk, 2010). With reference to the lexical level of translation the consequence is observed in terms of inter-language cluster equivalence patterns (Lewandowska-Tomaszczyk 2017), which will be exemplied in the forthcoming sections.

\section{Analysis of English integrity}

In order to exemplify and discuss cross-linguistic lexical patterns this section presents a corpus-based analysis of the English lexical form integrity from the persepctive of the use of corpus tools as applied to the set of criteria discussed above in contrastive studies (Altenberg and Granger 2002: 7, Barlow 2008) and translation. The frequency data generated both in monolingual English (BNC) and Polish (Przepiórkowski et al. 2012) national corpora as well as in English-to-Polish and Polish-to-English translation corpus by the parallel concordancer Paralela (Pęzik 2016), are completed with a survey of relevant collocational patterns. They are considered important analytic tools to determine degrees of equivalence and differences in the range of possible equivalence types.

\subsection{Lexicographic data}

The lexical semantic perspective on the form integrity ${ }^{13}$ provides the lexicographic definitions of the word as discussed below.

Integrity noun

The meaning of English integrity presents a complex cluster of properties, forming a polysemic network of senses in terms of a radial category. Radial categories contain a number of sub-category networks each with its own prototypical members (Rosch 1974), not necessarily predictable but combined by convention (Lakoff 1997). Integrity in this sense, as described in the major English dictionaries, involves first of all the sense of physical wholeness and completeness and is exemplified both with reference to human body (11) and to artefacts (12):

${ }^{13} \mathrm{https}: / /$ dictionary.cambridge.org/pl/dictionary/english/integrity 
(11) People who are dying, experience the ultimate threat to their bodily integrity through the changing ways in which their deteriorating bodies allow them to live

(12) A modern extension on the old building would ruin its architectural integrity.

Apart from the holistic sense and completeness, in its metaphoric extensions (Lakoff and Johnson 1980) integrity indicates one of this concept formative parts stability - as well as harmony, as in the extended reading of example (12) as well as stability of moral principles and unchanging moral standards as in:

(13) No one doubted that the president was a man of the highest integrity ${ }^{14}$.

A consulted range of integrity synonyms and antonyms ${ }^{15}$ to the form integrity serves as a testing criterion to support first the holistic - bodily - as well as artefactual perspectives on the broad meaning of the analysed form. The synonyms soundness, robustness, strength, sturdiness, solidity, solidness, durability, stability, stoutness, toughness and their anotonym fragility $^{16}$ refer to the first - physical sense of integrity as a complete whole.

What can be considered as a metonymic sense of integrity as togetherness physical and/or cognitive - is also clarified when corroborated by their synonyms: unity, unification, wholeness, coherence, cohesion, undividedness, togetherness, solidarity, or coalition as well as their antonyms e.g., division.

The extended - moral and emotional - senses of integrity on the other hand, are foregrounded both by the substitution synonymity test as well as by considering their synonymous meanings and antonyms such as honesty, uprightness, probity, rectitude, honour, honourableness, upstandingness, good character, principle(s). ethics, morals, righteousness, morality, nobility, high-mindedness, rightmindedness, noble-mindedness, virtue, decency, fairness, scrupulousness, sincerity, truthfulness, trustworthiness and the major antonym dishonesty.

The extensive meaning space of integrity is further visualized in the present study as a synonymy set, generated by the Sketch Engine tools fom the Web-based Thesaurus materials of over 20 billion unit size (Fig. 1). The synonyms reflect the two basic conceptual clusters, building the broad meaning of integrity around ethical accountability, confidence, etc. on the one hand, as well as physical and abstract stability versus diversity and flexibility on the other. The latter sense is particularly worth noting due to the presence of the polysemous antonymic senses (see Lewandowska-Tomaszczyk 2007 for antonymous polysemy), in which the meaning of integrity is captured in terms of a double-faceted diffused type of polysemy or synonymity, namely a combination of two contrasting senses: integrity as stability and, at the same time, its contrasting meaning, which surfaces in the

${ }^{14} \mathrm{https}$ ://www.cambridge.org/gb/cambridgeenglish/better-learning-insights/corpus

15 Sources: https://www.cambridge.org/gb/cambridgeenglish/better-learning-insights/corpus, https://languages.oup.com/google dictionary-en/

${ }^{16}$ Oxford Languages https://languages.oup.com/ 
data in the form of integrity as (stabilizing) diversity, frequently used in the neighbouring contexts, as demonstrated in Figure 1.

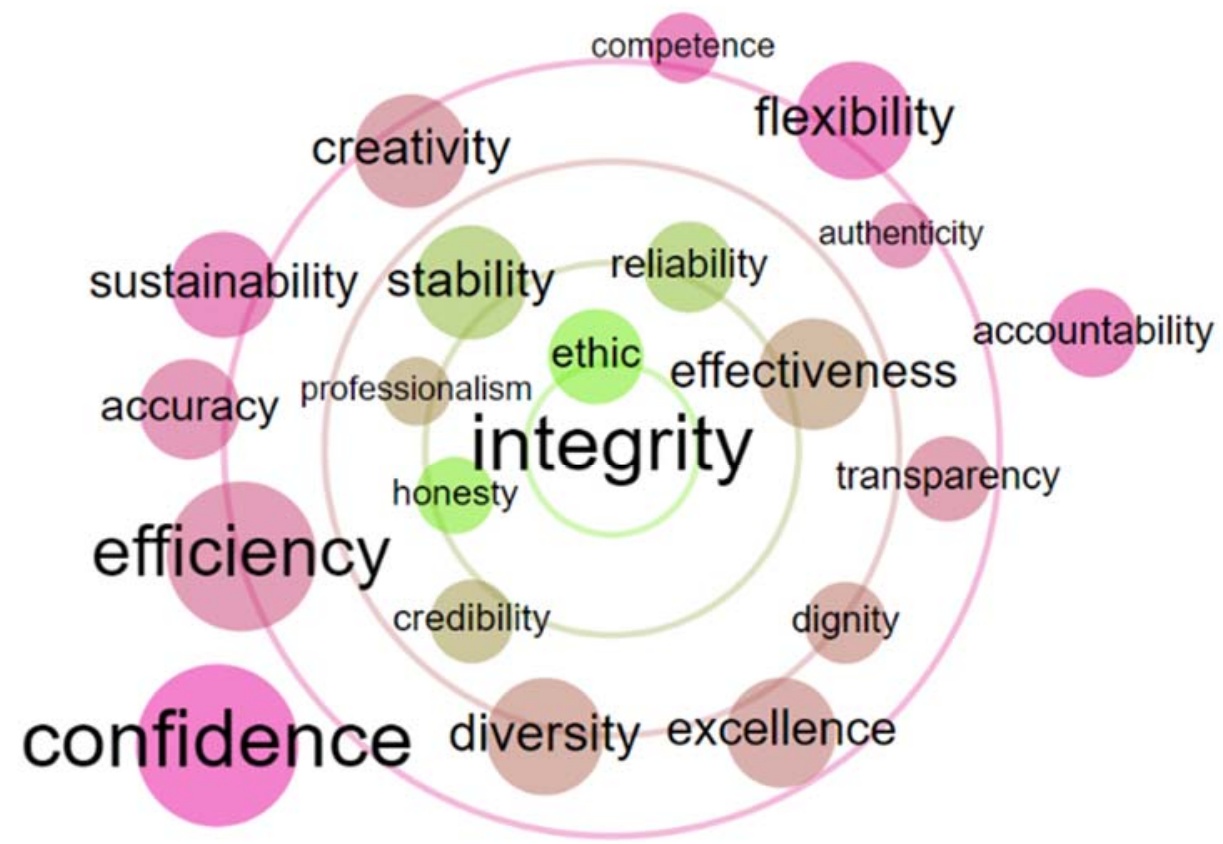

visualization by 63 SKETCH

Figure 1. Integrity synonyms

Source: https://www.sketchengine.eu/guide/thesaurus-synonyms-antonyms-similar-words/

The survey of the synonyms as presented above constitutes elements of larger clusters of the analyzed form. Meanings defined as conventionalised conceptualizations of our experience are framed in terms of Idealized Cognitve Models (Lakoff 1987), which represent larger frames of reference reflecting ways that human beings structure and understand elements of our experiences driven by our senses. Thus, the sense of integrity understood e.g., as honour in so-called honour cultures will not be identical to that in other cultures and may lead to different consequences in the real world (Sznycer et al. 2012).

The diversity of the senses of integrity as defined in dictionaries need also to be confronted with the collocation patterns e.g., patterns drawn from larger language data, here from the Britsh National Corpus and National Corpus of Polish, and generated by the PELCRA collocator (Pęzik 2012, 2014) from relevant texts. The collocational information contains information indicating particular sense framing ${ }^{17}$.

17 The collocator HASK developed by Pęzik (2014) provides access to lists of word combinations in pre-defined patterns in reference corpora of English and Polish. In addition to detailed statistics it is also possible to browse through the underlying concordances, visualise and download phraseological profiles for a given entry http://pelcra.clarin-pl.eu/hask_en/ 


\subsection{Collocations}

The use and distribution of collocation ranges can help test the scope of particular meanings and, through this, further clarify their senses. As a dominant property of a collocation is that their constituent words co-occur in language more often than by chance, such lexical combinations indicate particular sense connections in the expression. The TTest results provided in the tables below are used to determine statistical significance of such occurrences.

The collocations of the form integrity from the BNC include the collocates presented in Table $1^{18}$ : They demonstrate the varied polysemic senses of the form integrity in English.

Table 1

Adjectival collocates of integrity

\begin{tabular}{|c|l|c|c|c|}
\hline$\#$ & \multicolumn{1}{|c|}{ Collocate } & POS & A & TTEST \\
\hline 1 & territorial & AJ\% & 77.0 & 8.73 \\
\hline 2 & personal & AJ\% & 26.0 & 4.06 \\
\hline 3 & moral & AJ\% & 19.0 & 4.00 \\
\hline 4 & professional & AJ\% & 21.0 & 3.89 \\
\hline 5 & artistic & AJ\% & 15.0 & 3.75 \\
\hline 6 & offline & AJ\% & 14.0 & 3.70 \\
\hline 7 & structural & AJ\% & 12.0 & 3.22 \\
\hline 8 & physical & AJ\% & 14.0 & 2.97 \\
\hline 9 & referential & AJ\% & 7.0 & 2.62 \\
\hline 10 & mucosal & AJ\% & 4.0 & 1.89 \\
\hline 11 & political & AJ\% & 16.0 & 1.71 \\
\hline 12 & journalistic & AJ\% & 3.0 & 1.69 \\
\hline 13 & highest & AJ\% & 5.0 & 1.59 \\
\hline 14 & absolute & AJ\% & 4.0 & 1.48 \\
\hline 15 & scientific & AJ\% & 5.0 & 1.44 \\
\hline 16 & historic & AJ\% & 3.0 & 1.33 \\
\hline
\end{tabular}

The physical sense of integrity is identified in collocates $1,7,8$, its moral sense - in 2, 3, 4, 11, 12, 15, 16 in Table 1 . One of the adjectival collocation types profiles the moral integrity sense, which can be considered a (metaphorical) extension of physical integrity, perceived in terms of undividedness, stability and durability of physical matter, concepts listed above as possible integrity synonyms. The sense of togetherness is most salient in the nominal collocates 3 and 5 in Table 2, while the verbal collocates in Table 3 are more inclusive as they can refer to the varied integrity senses.

The data in Table 3 allow one to postulate another component in the cognitive interpretation of integrity, viz., the element of force dynamics. The phenomenon of force dynamics, first identified by Talmy (1985), refers to a meaning element of

${ }^{18} \mathrm{http}: / /$ pelcra.clarin-pl.eu/hask_en/browser? $=$ integrity\&pos $=\% 25 \& \operatorname{cpos}=\% 25$ 
Nominal collocates of integrity

\begin{tabular}{|c|l|c|c|c|}
\hline$\#$ & \multicolumn{1}{|c|}{ Collocate } & POS & A & TTEST \\
\hline 1 & check & N\% & 41.0 & 6.24 \\
\hline 2 & enhancement & N\% & 4.0 & 1.88 \\
\hline 3 & logic & N\% & 4.0 & 1.56 \\
\hline 4 & feature & N\% & 6.0 & 0.37 \\
\hline 5 & system & N\% & 3.0 & 11.26 \\
\hline
\end{tabular}

Table 3

Verbal collocates of integrity

\begin{tabular}{|c|l|c|c|c|}
\hline$\#$ & \multicolumn{1}{|c|}{ Collocate } & POS & A & TTEST \\
\hline 1 & maintain & V\% & 39.0 & 6.01 \\
\hline 2 & preserve & V\% & 21.0 & 4.48 \\
\hline 3 & question & V\% & 10.0 & 3.01 \\
\hline 4 & defend & V\% & 10.0 & 3.00 \\
\hline 5 & protect & V\% & 10.0 & 2.84 \\
\hline 6 & ensure & V\% & 11.0 & 2.81 \\
\hline 7 & undermine & V\% & 7.0 & 2.55 \\
\hline 8 & threaten & V\% & 7.0 & 2.37 \\
\hline 9 & respect & V\% & 6.0 & 2.36 \\
\hline 10 & retain & V\% & 7.0 & 2.35 \\
\hline 11 & check & V\% & 7.0 & 2.23 \\
\hline 12 & challenge & V\% & 5.0 & 2.03 \\
\hline 13 & lack & V\% & 5.0 & 2.00 \\
\hline 14 & destroy & V\% & 11.0 & 1.91 \\
\hline 15 & start & & & 1.88 \\
\hline
\end{tabular}

force an Agent exerts on an object. Such an element can be argued to be constitutive of the idea of integrity and lexically visible in most, if not all, verbal forms presented in Table 3. In these examples the basic prototypical sense indicates pressure upon the agent's body, emotions and/or mind which requires counteracting in order to maintain the agent's undivided, complete whole in the physical, emotional, or moral sense. In other words, disturbing outside forces threaten the bodily, emotional or moral wholeness of the agent, who - as a response - exerts force to counteract and counterbalance the outside pressure.

(14) I am not accustomed to having my integrity questioned

(15) The problem is that time is not on the side of those who wish to maintain the integrity of the nation state.

Some of the syntactic patterns of the integrity verbal collocates of one of the force-dynamic concepts 'to question' are visualized and interpreted below (Table 4). 


$$
\text { question + personal integrity }
$$

Frequency: 20

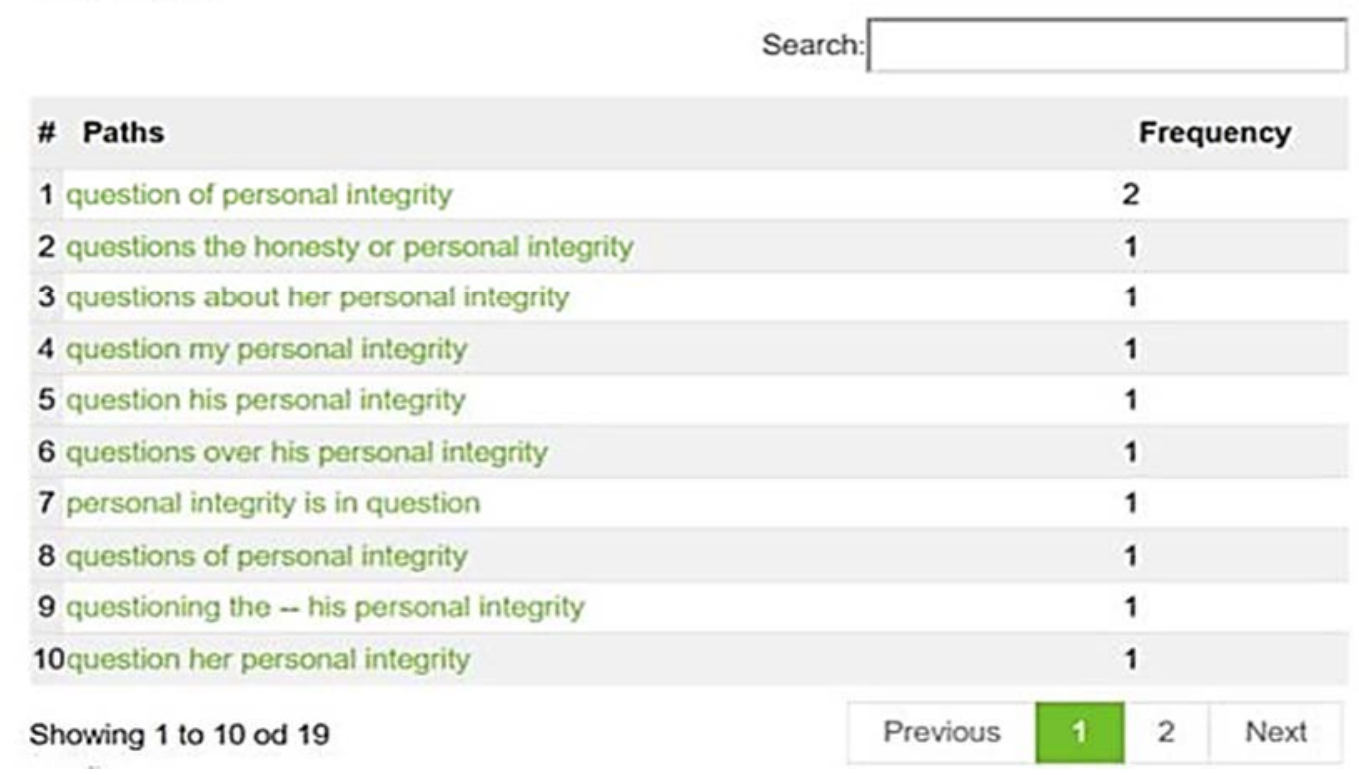

Table 4 presents morpho-syntactric patterns of the verb question-induced schema of occurrences, i.e., their construals in the Langackerian sense (1987). The item question can be considered a nominal form as in examples $(1,3,6,7,8)$, a verbal form in $(2,4,5,10)$, while in (9) it is a gerund. Each of these constructions is related to a particular shift in the semantic interpretration of an event expressed by these constructions. The contribution of syntactic properties to shaping an event is a part of each construction task for particular lexis and varies across languages.

Taken as a whole, the contribution of the synonymy and collocate ranges extend the range of the semantic analysis of the investigated word and presents directions which are taken in translations of the notion of integrity into other languages. They all constitute, as was observed before, a complex network of senses, which, together, can be claimed, to present a broad word meaning. This range of senses characterizing one lexical unit is made explicit in various translation options as exemplified by means of the parallel concordancer and collocator.

\section{Parallel corpus data: English-to-Polish and Polish-to-English}

Due to its highly polysemic character (Lewandowska-Tomaszczyk 2007) the English form integrity undergoes the processes of cluster equivalence patterning when compared to or translated into Polish. In Table 5 below results of the Paralela English-to-Polish translation search (Pęzik 2016) are shown. Needless to say, the direction of linguistic comparison does matter and leads to different results. 
In this Table an example of an English-to-Polish cluster equivalence pattern (Lewandowska-Tomaszczyk 2017) is presented:

Table 5

Eng. integrity in the parallel patterns in Polish translations

\begin{tabular}{|l|l|l|c|c|c|c|}
\hline$\#$ & \multicolumn{1}{|c|}{ Lemma } & \multicolumn{1}{|c|}{ Word forms } & A & B & C & Dice \\
\hline 1 & $\begin{array}{l}\text { integralność } \\
\text { 'integrity' }\end{array}$ & $\begin{array}{l}\text { [integralności, integralność, integralność, } \\
\text { integralności, integralnością, integralności, } \\
\text { integralności, integralności] }\end{array}$ & 829 & 1223 & 111 & 0.554 \\
\hline $\mathbf{l}$ & $\begin{array}{l}\text { uczciwość } \\
\text { 'honesty' }\end{array}$ & $\begin{array}{l}\text { [uczciwości, uczciwość, uczciwość, uczciwością, } \\
\text { uczciwości] }\end{array}$ & 233 & 1819 & 765 & 0.153 \\
\hline 4 & $\begin{array}{l}\text { terytorialny } \\
\text { 'territorial' }\end{array}$ & [terytorialnej, terytorialną, terytorialna] & 220 & 1832 & 1488 & 0.117 \\
\hline 5 & $\begin{array}{l}\text { niezależność } \\
\text { 'independence' }\end{array}$ & [niezależności, niezależność, niezależność] & 120 & 1932 & 2274 & 0.054 \\
\hline 6 & $\begin{array}{l}\text { rzetelność } \\
\text { 'reliability' }\end{array}$ & [rzetelności, rzetelność, rzetelność] & 66 & 1986 & 367 & 0.053 \\
\hline 7 & $\begin{array}{l}\text { prawość } \\
\text { 'righteousness' }\end{array}$ & [prawości, prawość, prawość] & 57 & 1995 & 192 & 0.050 \\
\hline 8 & $\begin{array}{l}\text { wiarygodność } \\
\text { 'credibility' }\end{array}$ & [wiarygodności, wiarygodność, wiarygodność] & 107 & 1945 & 2604 & 0.045 \\
\hline 9 & $\begin{array}{l}\text { nietykalność } \\
\text { 'inviolability' }\end{array}$ & [nietykalności, nietykalność] & & & 0.062 \\
\hline
\end{tabular}

Source: http://paralela.clarin-pl.eu/)

In the parallel data in Table 5 the two major senses of integrity are identified. However, these senses are polysemically, radially linked by one kind of the family resemblance relation (Wittgenstein 1953), and more precisely by shifting the conceptualized perceptual perspective on the same object (Langacker 1987). The first sense identifies an inner, internally stable, unchanging whole, physically or morally substantiated e.g., in (territorial) integrity, etc., and integrity in the sense of credibility, etc., on the one hand and on the other, the second sense indicates an implicational sense of integrity, which implies the presence of a boundary in order to separate one whole, unified entity from another as in the meaning of independence or sovereignity.

Each of the possible cluster equialents in the translation data yields its own cluster equivalent patterns when further contrasted with similar concepts in another language or translated into it, as can be seen in Table 6 in the case of Polish uczciwość 'honesty', one of the Polish equivalents of Eng. integrity. Each of the Target Language forms then opens up a new meaning space with a number of possible sense choices, each including as one of the alternatives, equivalents of the original concept, albeit tailored in varying ways by a particular cultural-linguistic context: 
Polish-to English parallel data of Pol. uczciwość 'honesty'

\begin{tabular}{|c|l|l|c|c|c|c|}
\hline$\#$ & \multicolumn{1}{|c|}{ Lemma } & \multicolumn{1}{c|}{ Word forms } & A & B & C & Dice \\
\hline 1 & honesty & [honesty, honesty] & 161 & 339 & 794 & 0.221 \\
\hline 2 & integrity & [integrity, integrity] & 104 & 396 & 1990 & 0.080 \\
\hline 3 & fairness & [fairness, fairness] & 36 & 464 & 562 & 0.066 \\
\hline 4 & sincerity & [sincerity, sincerity] & 9 & 491 & 325 & 0.022 \\
\hline 5 & decency & [decency] & 11 & 489 & 537 & 0.021 \\
\hline 6 & probity & [probity] & 5 & 495 & 17 & 0.019 \\
\hline 7 & objectivity & [objectivity] & 7 & 493 & 248 & 0.019 \\
\hline 8 & wed & [wedded] & 6 & 494 & 291 & 0.015 \\
\hline 9 & forsake & [forsaking] & 3 & 496 & 39 & 0.015 \\
\hline 10 & troth & [troth] & & & & \\
\hline
\end{tabular}

Together with the identification of syntactic/semantic preferences between particular words and constructions (Stefanowitch and Gries 2003), as well as pragmatic and emergent interactional effects, there are grounds to suggest that the performed data analysis may shed more light on cross-linguistic understanding of meaning differences.

\section{Cognitive tertia comparationis}

The search for the properties which would anchor down a cross-linguistic comparison is curbed by the fact that there is little to be found in the world languages that could be considered substantially identical. Rather, what is observed is a contrastive skeleton, or frame, in which certain properties are a constant. What can be predominantly identified are cognitive tertia on the one hand and universal procedural and structural universals of different types on the other.

Cognitive Tertia Comparationis in comparing languages cover a number of human cognitive abilities and involve analogy, abstraction, metaphorization, as well as combinatorial powers such as possibly Chomsky's recursion properties (cf. Hauser, Chomsky, \& Fitch, 2002).

The basic cognitive parameter subsumed under the human capacity of analogy and abstraction belongs to the ability of categorizing objects and phenomena and its main attributes, such as the representation in terms of basic image schemas, schematic category structures, comprising prototypical and peripheral category members, combined into larger Idealised Cognitive Models, culturally and contextually bound (Lakoff, 1987). The criterial feature of these structures is their partial compositionality and the presence of on-line meaning building mechanisms in terms of emerging structures.

The concept of a prototype and its peripheral members which translate to a certain extent to the idea of polysemic networks of senses (LewandowskaTomaszczyk 2007), frequently in terms of radial categories (Lakoff 1987), can be considered one of the basic elements to investigate in cross-linguistic cognitive semantic comparisons. In the case of integrity it is the element of a 'physical integration of individual parts' that plays the prototypical role in the basic sense of 
this concept. The metaphotical extension of 'keeping the self-identity elements together' is connected with the extended metaphorical sense of integrity immersed in the ethical frame of reference and refers to as internal consistency considered a virtue. Its polysemous antonymic counterpart mentioned above is alone an opposite replica of the former, similarly to negation, which hypostatizes absence albeit with reference to the identical cognitive-structural constitutents present in its positive counterpart (Lewandowska-Tomaszczyk 1996).

Although the universal processes in cross-linguistic tasks such as human abilities and metaphorization processes play a formative part in these extensions, a cross-linguistic analysis of concepts uncovers processes of re-conceptualization of the incoming $L 1$ material into modified or new networks of senses in which the originally combined elements appear to be members of distinct - albeit related networks of senses as is the case in the English-to-Polish counterparts of integrity. Such processes invariably lead to another important element of the semantic comparisons, namely conceptual approximation of the output material when compared to that in other languages. In other words, no linguistic or any other semantic (or in fact semiotic) representation will be the only full mirror of the outside world. A linguistic structure is an outcome of a number of cognitive operations starting with the parameters of construal, focusing, perspectivizing, etc. (cf. Langacker 1987, 1991) that lead to the re-conceptualization processes, portraying as in the present study, the transformation of the English semantic cluster of intergrity, independence, sovereignity into a comparable network of cluster senses in Polish, embracing integralność, niezależność, niezawisłość, suwerenność, etc.

\section{Culture}

The impact of culture on meanings, where culture is understood as conventional i.e., including shared patterns of thinking, imagery and practices, cannot be ignored (Lewandowska-Tomaszczyk \& Wilson 2013, Sharifian 2017). Hofstede (1980), and later Trompenaars and Hampden-Turner (1997) were first to propose systems of cultural diemensions to identify cultural differences defined in terms of responses to quantified questionnaire-based dimensions. In the case of integrity, the cultural dimension of UK high individualism (97 on the scale of 100) as contrasted with the Polish rather middle position between the dimensions of collectivism and individualism (60), seem to play a role, as additionally evidenced by the collocation corpus data. In both Polish and English materials territorial integrity (Table 1) and its Polish counterpart integralność terytorialna ${ }^{19}$ (Table 7) occupy the top positions on the respective Adjectival collocate lists. On the other hand, the consulted language materials present a significantly higher frequency of occurance of the collocation personal integrity in the British materials 2nd position on the Adjectival collocates lists (Table 1), when compared to comparable cluster concepts of the direct cognate equivalent form 'integralność' in

${ }^{19}$ Consult http://pelcra.clarin-pl.eu/hask_pl/browser?eh=caa447t267a31ab9a64b921c43332971 
Polish scrutinized for the adjectival collocates (Table 7), even ignoring the fact for the time being that in many cases Polish uses distinct lexical forms to name this sense of integrity. However, generally, while the position of personal identity is the second most frequent one in English, in Polish it emerges in the $15^{\text {th }}$ position, reinforced to a certain degree by the adjectives wtasny 'own' $-8^{\text {th }}$, and swój 'one's (own)' $-11^{\text {th }}$, from the same conceptual field.

Table 7

Adjectival collocates of Polish integralność

\begin{tabular}{|c|l|c|c|c|}
\hline$\#$ & \multicolumn{1}{|c|}{ Collocate } & POS & A & TTEST English equivalent \\
\hline 1 & terytorialny & Adj & 117.0 & 10.79 'territorial' \\
\hline 2 & cielesny & $\mathrm{Adj}$ & 14.0 & 3.73 'bodily' \\
\hline 3 & fizyczny & $\mathrm{Adj}$ & 10.0 & 2.98 'physical' \\
\hline 4 & ludzki & $\mathrm{Adj}$ & 10.0 & 2.91 'human' \\
\hline 5 & rozwodowy & $\mathrm{Adj}$ & 8.0 & 2.82 'divorce'20 \\
\hline 6 & finansowy & $\mathrm{Adj}$ & 8.0 & 2.32 'financial' \\
\hline 7 & psychiczny & $\mathrm{Adj}$ & 5.0 & 2.17 'psychic' \\
\hline 8 & własny & $\mathrm{Adj}$ & 8.0 & 1.97 'own' \\
\hline 9 & komórkowy & $\mathrm{Adj}$ & 4.0 & 1.89 'cellural' \\
\hline 10 & moralny & $\mathrm{Adj}$ & 4.0 & 1.73 'one's (own)' \\
\hline 11 & swój & $\mathrm{Adj}$ & 18.0 & 1.72 'referential' \\
\hline 12 & referencyjny & $\mathrm{Adj}$ & 3.0 & 1.52 'state' \\
\hline 13 & państwowy & $\mathrm{Adj}$ & 4.0 & 1.52 'artistic' \\
\hline 14 & artystyczny & $\mathrm{Adj}$ & 3.0 & $1.45^{\prime}$ 'personal' \\
\hline 15 & osobisty & $\mathrm{Adj}$ & 3.0 & \\
\hline
\end{tabular}

Apart from the terminological uses integralność rozwodowa (5th in Table 7, ft. 20) and others such as finansowa 'financial integrity' $-6^{\text {th }}$ in Table 7, constrained to professional senses, another terminological extension of the Polish form integralność as used in logistics and computer science (integralność danych lit. 'data integrity' in the sense of Eng. software integrity), in the sense of software and data security. In both computer senses as well as in the psychological/philosophical uses, addressed in Section 7.1. below, the Polish cognate equivalent term integracja is a loan based on English integrity which might account for their closer semantic resemblance to English meanings in the Polish language. These senses are semantically a part of the 'completenes, stability' cluster of integrity, with an implicational element of reliability, which might be argued to be a property of the conventional conceptual sense of security and safety.

All of the analysed senses of English integrity, discussed on the semasiological and onomasiological planes, are based on two basic mental models and their extensions, networked by a number of constituent prototypes which, together, form a complex radial category of the meaning of this form.

${ }^{20}$ Pol. integralność rozwodowa Eng. 'integrity of court (divorce) ruling on guilt' is a term in Polish legal system referring to court ruling on guilt in divorce cases. 
To conclude this section one needs to re-emphasize the role of the linguistic typological frames of reference, which give rise to language-specific constructional and semantic frames with a range of distinct analysability criteria and construal principles, including degrees of prominence of a scene, action parameters, figure/ground relations, degrees of schematicity (cf. the coarse- vs. fine-grained picture), scope of predication, and force-dynamic relations in the Cognitive Linguistic frame of reference (Langacker 1987/1991). Typologically distinct cognitive linguistic construal types in cross-linguistic comparisons are outcomes of the interaction of such variables in a linguistic system. A description of culture in terms of the cultural dimensions as devised by Gert Hofstede (1980, 1983), also enriched by considering what Pierre Nora (2002) calls lieux de memoire, which refer to outside world cultural artefacts, symbols and sites, have thus been refined by instruments of corpus-based evidence.

\subsection{Cultural conceptualizations}

In order to detail the basis of the interlinguistic cultural meaning system analysis, the semantic effects of the cultural conceptualizations perspective as proposed by Sharifian (2003) should be considered. By extending the notion of cognition to embrace action and socially situated activity, Bernárdez, Sharifian and others (Sharifian 2013) elaborated on the concepts of embodiment and situatedness to accept that cognition is mediated by human bodily experience.

The interaction between cognition and culture - the subject of numerous interdisciplinary studies (e.g., Tomasello 1999) - is captured by Farzad Sharifian in terms of interactions between the members of a cultural group across time and space, "instantiated in various aspects of people's lives including aspects of their physical environments, artefacts, tools, rituals" (Sharifian 2008: 112), and embracing their patterns of thoughts and judgments.

Taking this position as a point of reference one might propose that the complexity of the integrity meaning is not only due to its polysemic character in the language system. Rather, or even primarily, it integrates the ambivalence in its double-faceted, physical - moral character, enriched by the contribution of people's thinking and acting. It is precisely the analysis of people's thinking and acting, which is constituting the onomasiological basis of meaning construction that might provide fudamental clues with regard to the categorial status and range of senses of this language form.

In the paper What it means to have integrity in the 21st century authored by Rachael Wiseman, Charlotte Alston and Amber Carpenter and posted on the British Academy blog on $30 \mathrm{Aug} 2018^{21}$, the authors propose: "Integrity matters to us. We want representatives who will speak truth to power and who won't be bought by that power. We want our children to learn to be true to themselves, rather than pulled this way and that by trends on social media. We want to be someone who, when there is a tough choice between what is right and what is easy, will do what

${ }^{21} \mathrm{https}$ //www.thebritishacademy.ac.uk/blog/integrity-in-the-21st-century/ 
is right. But we are also ambivalent about integrity, and for good reason. Someone who speaks and acts with integrity often makes life uncomfortable for those around her. A person who stands up to authority may put their friends, families or community in danger or difficulty."

In a similar vein, Mattinson (The Guardian: 3 Sept 2017) ${ }^{22}$ reports on a research team who asked members of a focus group in England to explain what they meant by integrity. The subjects tried to explain integrity by using the paraphrases such as "being yourself" and "sticking to your beliefs". One can agree with Mattinson then, who suggests that integrity is more than just honesty for these people. Integrity embraces ways of conduct and thinking, "being well intentioned", "putting people first" and being "someone to look up to". Thinking, situatedness, acting have to be referred to then, in order to account for the conceptual-lexical complexity of integrity and at the same time profile the cultural aspects of the conceptualization of this form.

There is no one Polish equivalent to English integrity. The sense of Pol. integralność, to take its cognate cluster equivalent, shows one side of the two sidedeness of the English integrity meaning, and is related to the idea of wholeness, prototypically in its physical sense as in integralność terytorialna 'territorial integrity ${ }^{23}$. The form integralość is significantly less frequent in an extended sense in Polish, although used as a term, e.g., in the legal sysem, as it surfaced in the collocation tables, or is applied in the holistic philosophical and psychological systems, where it refers to a unity of body, mind and, spirit, and is rooted in Eastern philosophy and religion, also currently present e.g., in the Three in One Concepts ${ }^{\circledR}(\mathrm{TIOC})$ popular applied psychology approach (Stokes and Whiteside 1997).

Other Polish equivalence cluster members of English integrity correspond, as exemplified in Table 5, to lexical forms of diverse derivational origins and are linked to some of the English synonyms as presented in Fig. 1. In other words, although conceptually linked, they are not generally perceived in Polish, differently than in English, as members of the same lexical-conceptual entity, in which physical and moral senses are united in a harmonious proportion.

\section{Parametrization of Contrastive Analysis criteria}

A systematic survey of the contrastive linguistic analysis criteria as presented in the sections above, assumes a further division of the model discussed in this study into the qualitative and quantitative criteria.

The qualitative criteria embrace prototypical and more complex radial category comparison ${ }^{24}$ in different language systems and capture perceptual,

${ }^{22} \mathrm{https} / /$ www.theguardian.com/politics/2017/sep/02/what-does-britain-want-in-leader-integrityempathy-authenticity

${ }^{23}$ integralny «nierozdzielnie związany z całością» • integralnie • integralność

integralność terytorialna «W prawie międzynarodowym: nienaruszalność całości terytorium państwa» Source: https://sjp.pwn.pl/slowniki/integralno\%C5\%9B\%C4\%87.html

${ }^{24}$ See Lakoff (1987) for a discussion of the radial category of mother. 
functional, emotional, axiological, logical, and associate parameters of the units, considering also various figurative extension tropes of the conventional and creative types.

The structural properties of the construction, signalling its conceptual construal types as well as its discourse / interactional attributes, are the properties contributing to meaning making of the whole utterance. Cognitive semantics considers the construction of meaning both at the level of the sentence (Goldberg $2003,2006)$ and at the level of the lexeme in terms of the structure of concept as envisaged above. Constructions in the sense of Goldberg (1995:39) function in the vein of the general principles of Cognitive Grammar, which assumes the formmeaning iconicity (Haiman 1980), reflected in that syntactic organization encodes semantic information on human experiences through structures representing events, their properties and participants e.g., transfer, location, cause, result and so on. Apart from these characteristics, construction in Langacker's interpretation (1987) also involves the processes of construing of particular cultural-linguistic conceptualization types, which constitute a broad system of contrastive linguistic parametric properties used in the cross-linguistic identification of similarities and contrasts.

Such a model contributes to a better understanding of the perennial problem of translation, namely the concept of translational equivalence through the identification of contrastive research criteria. In this vein, a typology of translational cluster equivalence, which embraces the categories based on the parameters discussed in the sections above, was proposed in Lewandowska-Tomaszczyk (2017) and involves a system of equivalence patterns (22):

\section{System of translational equivalence patterns}

I. Trivial equivalence (with full commensurability)

II. Non-trivial equivalence

a. Derived (equivalence from corresponding inter-linguistic clusters)

b. Extended (equivalence embracing corresponding causes, results, and/or presuppositions)

c. Creative (extending beyond conventional linguistic and cultural limits)

A new definition of translation which evolves from such an approach (Lewandowska-Tomaszczyk 2020) considers translation as a creative re-conceptualization of the original, inspired by and making informed choices from spaces of meanings, which involve a selection of mental models in the sense of Gilles Fauconnier (1984) and George Lakoff (1987). Firstly, there are structures that contain Image Schematic Models of reality i.e., schematic models of outside reality, involving image-schematic representations e.g., UP-DOWN or CONTAINER models. Such models are argued to establish patterns of human understanding and reasoning, often in terms of metaphoric mappings (Lakoff 1987: 284). Secondly, chunks of knowledge, immersed in their situational and cultural contexts, are parts of, above mentioned, Idealized Cognitive Models (ICMs). Both types of mental models can be stimulated to extend over and above conventional understanding and produce models of novel senses of objects and events. In the 
spaces of meaning in which default ICMs are located, modified and new meanings and mental constructions can be instigated and liguistically labelled, somewhat beyond Fregeian fully compositional sets of lexical senses (Frege 1966 [1919]).

Such an understanding of spaces of meanings defines - to a large extent a creative identity of writers and translators as well as the imagination of other individuals who may build less conventional mental constructions in Extended Reality worlds. In the case of such practices, it is the personal identity, predilections and preferences, as well as the degree of the language users' creative cognitive and linguistic gifts that play an important role. Such practices make it also possible for language users to move outside the assumed meaning boundaries and breach the culturally accepted conventional conceptualization barriers to form novel extensions and metaphorical blends (Fauconnier \& Turner 1998).

\section{Conclusions}

The main objective of the paper was to present conceptual and linguistic issues with regard to unambiguous, unique interpretations of linguistic meanings in the monolingual and multilingual perspectives as well as the use of available cognitively founded corpus-based methodologies to uncover such phenomena on the one hand as well as to reconcile the problematic areas for the sake of crosslinguistic comparisons. The English form integrity and its available Polish correspondences were taken as the exemplification of such a state of affairs and, furthermore, in order to establish possible anchoring comparison areas - crosslinguistic tertia comparationis - to serve as a set of parameters as well as crosslinguistic comparison criteria.

The definitional tertium comparationis and cross-linguistic equivalence criteria thus involve as discussed in the present study both cultural conventional imagery in terms of onomasiological criteria, structural criteria of the semasiological basis as well as construal principles combining those perspectives in terms of the parameters recognized in the cognitive cultural linguistic models. The dynamic nature of linguistic meanings and their unstable boundaries account for the need to employ those different tools and instruments as in this work to identify conceptual semantic and constructional subtleties in one language as well as in a contrastive linguistic design.

(C) Barbara Lewandowska-Tomaszczyk, 2021 @ccreative

This work is licensed under a Creative Commons Attribution 4.0 International License https://creativecommons.org/licenses/by/4.0/

\section{REFERENCES}

Altenberg, Bengt \& Sylviane Granger. 2002. Recent trends in cross-linguistic lexical studies. In Bengt Altenberg \& Sylviane Granger (eds.), Lexis in Contrast. Corpus-Based Approaches, 3-48. Amsterdam: Benjamins. 
Austin, John L. 1955. How to Do Things with Words. Oxford: Oxford University Press.

Barlow, Michael. 2008. Parallel texts and corpus-based contrastive analysis. In: Maria de los Ángeles Gómez González, J. Lachlan Mackenzie \& Elsa M. González Álvarez. Current Trends in Contrastive Linguistics: Functional and cognitive perspectives [Studies in Functional and Structural Linguistics 60]. 101-121. Amsterdam: Benjamins.

Ba-awaidhan, Awad Gumaan. 2020. Cycles of conceptualization and reconceptualization in translating figurative language (with a special focus on selected Arabic-English proverbs). In Barbara Lewandowska-Tomaszczyk (ed.), Cultural onceptualizations in translation and language applications, 47-63. Cham: Springer Nature.

Dziwirek, Katarzyna \& Barbara Lewandowska-Tomaszczyk. 2010. Complex Emotions and Grammatical Mismatches. Berlin: Mouton de Gryuter.

Fauconnier, Gilles. 1994. Mental Spaces. Aspects of Meaning Construction in Natural Language. New York: Cambridge University Press.

Fauconnier, Gilles \& Mark Turner. 1998. Conceptual integration networks. Cognitive Science 22 (2). 133-187.

Fillmore, Charles. 1985. Frames and the semantics of understanding. Quaderni di Semantica VI. 222-254.

Frege, Gottleb. 1966 [1919]. Negation. In Peter Geach \& Max Black (eds.), Translations from the Philosophical Writings of Gottlob Frege, 117-135. Oxford: Blackwell. First published in (1919) Beitrdge zur Philosophie des deutschen Idealismus, vol. I. 143-157.

Geeraerts, Dirk. 2015. Quantitative corpus onomasiology. Conceptual Change - Digital Humanities Case Studies Lectures given on 7 Dec - 8 Dec 2015. KU Leuven.

Gladkova, Anna \& Tatiana Larina. 2018a. Anna Wierzbicka, words and the world. Russian Journal of Linguistics 22 (3). 499-520. DOI: https://doi.org/10.22363/2312-9182-201822-3-499-520

Gladkova, Anna \& Tatiana Larina. 2018b. Anna Wierzbicka, Language, culture and communication. Russian Journal of Linguistics 22 (4). 717-748. DOI: https://doi.org/ 10.22363/2312-9182-2018-22-4-717-748

Goddard, Cliff \& Anna Wierzbicka. 2014. Words and Meanings: Lexical Semantics Across Domains, Languages, and Cultures. Oxford: Oxford University Press.

Goldberg, Adele. 1995. A Construction Grammar Approach to Argument Structure. Chicago: University of Chicago Press.

Goldberg, Adele E. 2003. Constructions: a new theoretical approach to language. Trends in Cognitive Sciences 7 (5). Amsterdam: Elsevier Science Publishing Company, Inc. 219-224.

Goldberg Adele E. 2006. Constructions at Work: The Nature of Generalization in Language. Oxford: Oxford University Press.

Haiman, John. 1980. Iconicity of Grammar: Isomorphism and Motivation. Language 56/3. $515-540$.

Hauser, Marc D., Noam Chomsky \&. W. Tecumseh Fitch. 2002. The faculty of language: What is it, who has it, and how did it evolve. Science 298. 1569-1579.

Hofstede, Geert 1980. Culture's Consequences: International Differences in Work-Related Values. Beverly Hills: Sage.

Lakoff, George. 1987. Women, Fire and Dangerous Things: What Categories Reveal about Human Mind. Chicago: University of Chicago Press.

Lakoff, George \& Mark Johnson. 1980. Metaphors We Live By. Chicago: Chicago University Press.

Langacker, Ronald W. 1987-1991. Foundations of Cognitive Grammar, vols. 1-2. Stanford: Stanford University Press. 
Langacker, Ronald W. 2008. Cognitive Grammar: A Basic Introduction. Oxford: Oxford University Press.

Larina, Tatiana, Vladimir Ozyumenko \& Svetlana Kurteš. 2020. Deconstructing the linguacultural underpinnings of tolerance: Anglo-Slavonic perspectives. Lodz Papers in Pragmatics 16 (2). 203-234.

Lewandowska-Tomaszczyk, Barbara. 1989. Praising and complimenting. In Wiesław Oleksy (ed.). Contrastive pragmatics, 73-100. Amsterdam: John Benjamins Publishing Co.

Lewandowska-Tomaszczyk, Barbara. 1996. Depth of Negation - A Cognitive-Semantic Study, Lodz: Lodz University Press.

Lewandowska-Tomaszczyk, Barbara. 2007. Polysemy, prototypes, and radial categories. In Dirk Geeraerts \& Hubert Cuyckens (eds.), The Oxford handbook of Cognitive Linguistics, 139-169. Oxford: Oxford University Press.

Lewandowska-Tomaszczyk, Barbara. 2010. Re-conceptualization and the emergence of discourse meaning as a theory of translation. In Barbara Lewandowska-Tomaszczyk \& Marcel Thelen (eds.), Meaning in translation, 105-148. Frankfurt: Peter Lang.

Lewandowska-Tomaszczyk, Barbara. 2012a. Explicit and tacit: An interplay of the quantitative and qualitative approaches to translation. In Michael Oakes, P. \& Ji Men (eds.), Quantitative methods in corpus-based translation studies: A practical guide to descriptive translation research, 1-34. Amsterdam: John Benjamins Publishing.

Lewandowska-Tomaszczyk, Barbara. 2012. Cognitive corpus analysis - A new agenda for Contrastive Studies. Connexion - A Journal of Humanities and Social Sciences, 29-63.

Lewandowska-Tomaszczyk, Barbara. 2017. Cluster equivalence, general language, and language for specific purposes. In Marcin Grygiel (ed.), Cognitive approaches to specialist language, 384-418. Newcastle upon Tyne: Cambridge Scholars Publishing.

Lewandowska-Tomaszczyk, Barbara. 2020. Spaces of meaning and translators' identities. Lublin Studies in Modern Languages and Literatures 44 (1). Maria Curie-Sklodowska University Press. 11-26.

Lewandowska-Tomaszczyk, Barbara \& Paul A. Wilson. 2013. English fear and Polish strach in contrast: GRID approach and cognitive corpus linguistic methodology. In Johnny J. R Fontaine, Klaus R. Scherer \& Cristina Soriano (eds.), Components of Emotional Meaning: A Sourcebook, 425-436. Oxford: Oxford University Press.

Nora, Pierre. 1992. Les Lieux de Memoire. Paris: Gallimard.

Palmer, Gary B. 1996. Toward a Theory of Cultural Linguistics. Austin: University of Texas Press.

Pęzik, Piotr. 2012. Wyszukiwarka PELCRA dla danych NKJP. In Adam Przepiórkowski, Mirosław Bańko, Rafał Górski \& Barbara Lewandowska-Tomaszczyk (eds.), Narodowy Korpus Języka Polskiego, 253-279. Warsaw: Wydawnictwo Naukowe PWN.

Pezik, Piotr. 2014. Graph-based analysis of collocational profiles. In Vida Jesenšek \& Peter Grzybek (eds.), Phraseologie im Wörterbuch und Korpus, 227-243. Praha: ZORA 97 Filozofska fakuteta.

Pęzik, Piotr. 2016. Exploring phraseological equivalence with Paralela. In E. Gruszczyńska \& Agnieszka Leńko-Szymańska (eds.), Polish-Language Parallel Corpora, 67-81. Warsaw: Instytut Lingwistyki Stosowanej.

Przepiórkowski, Adam, Mirosław Bańko, Rafał Górski \& Barbara Lewandowska-Tomaszczyk. 2012. Narodowy Korpus Jezyka Polskiego [National Corpus of Polish]. Warszawa: Wydawnictwo PWN.

Rosch, Eleonor. 1973. Natural categories. Cognitive Psychology 4. 328-350. 
Sdobnikov, Vadim. 2019. Translation Studies Today: Old Problems and New Challenges. Russian Journal of Linguistics 23 (2). 295-327. DOI: https://doi.org/10.22363/23129182-2019-23-2-295-327

Sharifian, Farzad. 2003. On cultural conceptualisations. Journal of Cognition and Culture (3) 3. 187-207.

Sharifian, Farzad. 2008. Distributed, emergent cultural cognition, conceptualisation, and language. In Roslyn M. Frank, René Dirven, Tom Ziemke \& Enrique Bernárdez (eds.), Body, Language, and Mind (Vol. 2): Sociocultural Situatedness, 109-136. Berlin/New York: Mouton de Gruyter.

Sharifian, Farzad. 2017. Cultural Linguistics. Amsterdam: Benjamins.

Snell-Hornby, Mary. 2006. The Turns of Translation Studies. New Paradigms or Shifting Viewpoints? Amsterdam/Philadelphia: John Benjamins.

Stefanowitsch, Anatol \& Stefan Th. Gries. 2003. Collostructions: Investigating the interaction between words and constructions. International Journal of Corpus Linguistics 8 (2). 209-243.

Stokes, Gordon \& Daniel Whiteside. 1997. Tools of the Trade. Burbank: Community Builders Publishing LLC.

Sznycer, Daniel, Kosuke Takemura, Andrew W. Delton, Kosuke Sato, Theresa Robertson, Leda Cosmides \& John Tooby. 2012. Cross-cultural differences and similarities in proneness to shame: An adaptionist and ecological approach. Evolutionary Psychology 10 (2). 352-370.

Talmy, Leonard. 1985. Force Dynamics in language and thought. Papers from the Regional Meetings, Chicago Linguistic Society 21. 293-337.

Tirado, Rafael Guzmán. 2019. Translation of words with a cultural component (Based on the Spanish translation of the novel by Eugene Vodolazkin "The Aviator"). Russian Journal of Linguistics 23 (2). 473-486. DOI: https://doi.org/10.22363/2312-9182-201923-2-473-486

Tomasello, Michael. 1999. The Cultural Origins of Human Cognition. Cambridge, Mass.: Harvard University Press.

Trompenaars, Fons \& Charles Hampden-Turner. 1997. Riding the Waves of Culture: Understanding Cultural Diversity in Business. 2nd edn. London \& Santa Rosa: Nicholas Brealey Publishing Limited.

Vendler, Zeno. 1957. Verbs and Times. Philosophical Review 66. 143-160.

von Wright, Georg H. 1963. Norm and Action. A Logical Inquiry. London: Routledge and KegaPaul.

Wierzbicka, Anna. 1992. Semantics, Culture, and Cognition: Universal Human Concepts in Culture-specific Configarations. Oxford University Press.

Wierzbicka, Anna. 1997. Understanding Cultures through Their Key Words: English, Russian, Polish, German, and Japanese. Oxford: Oxford University Press.

Wittgenstein, Ludwig. 1953. Philosophical Investigations, translated by G.E.M. Anscombe. Oxford: Basil Blackwell.

\section{Corpora and Corpus Tools}

British National Corpus (BNC) http://www.natcorp.ox.ac.uk/

National Corpus of Polish (nkjp.pl) Narodowy Korpus Języka Polskiego (NKJP)। http://nkjp.uni.lodz.pl/

PELCRA_CLARIN Tools http://pelcra.clarin-pl.eu/

Paralela

Sketch Engine https://www.sketchengine.eu 
Article history:

Received: 16 November 2020

Accepted: 2 February 2021

\section{История статьи:}

Дата поступления в редакцию: 16 ноября 2020

Дата принятия к печати: 2 февраля 2021

\section{Bionote:}

Barbara LEWANDOWSKA-TOMASZCZYK is full Professor Dr habil. in Linguistics and English Language at the Department of Language and Communication of the State University of Applied Sciences in Konin (Poland), formerly employed at the University of Lodz. Her research focuses on cognitive semantics and pragmatics of language contrasts, corpus linguistics and their applications in translation studies, lexicography and online discourse analysis. She is invited to read papers at international conferences and to lecture and conduct seminars at universities. She publishes extensively, supervises dissertations and is also active organizing international conferences and workshops.

\section{Contact information:}

State University of Applied Sciences in Konin

1, Przyjazni str.

62510 Konin, Poland

e-mail: barbara.lewandowska-tomaszczyk@konin.edu.pl

ORCID: 0000-0002-6836-3321

\section{Сведения об авторе:}

Барбара ЛЕВАНДОВСКА-ТОМАШЧИК - профессор в области лингвистики и английского языка на кафедре языка и коммуникации Государственного университета прикладных наук в Конине (Польша), ранее работала в Лодзинском университете. Ее исследования сосредоточены на на контрастивных исследованиях в области семантики и прагматики, корпусной лингвистике и переводоведении, лексикографии и анализе онлайн-дискурса. Выступает с докладами на международных конференциях, читает лекции и проводит семинары в университетах. Активно публикуется, руководит диссертациями, а также организует международные конференции и семинары.

\section{Контактная информация:}

State University of Applied Sciences in Konin

1, Przyjazni str.

62510 Konin, Poland

e-mail: barbara.lewandowska-tomaszczyk@konin.edu.pl

ORCID: 0000-0002-6836-3321 